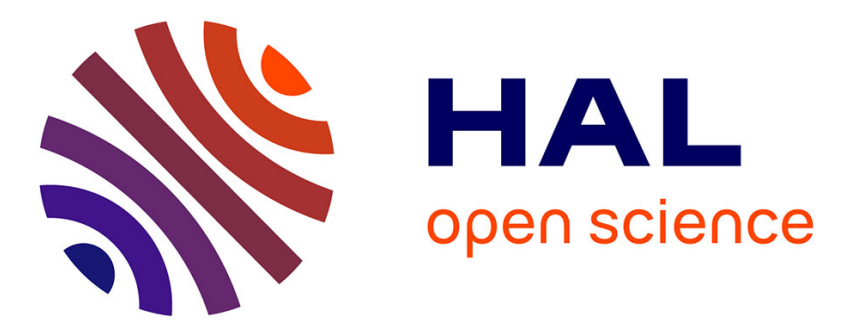

\title{
Triple-Slot Phase-Shifting Cell of Reduced Size for Reflectarray Applications
}

\author{
Tony Makdissy, Raphaël Gillard, Erwan Fourn, Etienne Girard
}

\section{To cite this version:}

Tony Makdissy, Raphaël Gillard, Erwan Fourn, Etienne Girard. Triple-Slot Phase-Shifting Cell of Reduced Size for Reflectarray Applications. 8th European Conference on Antennas and Propagation, (EuCAP 2014), Apr 2014, La Haye, Netherlands. 10.1109/EuCAP.2014.6902094 · hal-01108236

\section{HAL Id: hal-01108236 \\ https://hal.science/hal-01108236}

Submitted on 22 Jan 2015

HAL is a multi-disciplinary open access archive for the deposit and dissemination of scientific research documents, whether they are published or not. The documents may come from teaching and research institutions in France or abroad, or from public or private research centers.
L'archive ouverte pluridisciplinaire HAL, est destinée au dépôt et à la diffusion de documents scientifiques de niveau recherche, publiés ou non, émanant des établissements d'enseignement et de recherche français ou étrangers, des laboratoires publics ou privés. 


\title{
Triple-Slot Phase-Shifting Cell of Reduced Size for Reflectarray Applications
}

\author{
Tony Makdissy ${ }^{1}$, Raphaël Gillard ${ }^{1}$, Erwan Fourn ${ }^{1}$, Etienne Girard ${ }^{2}$ \\ ${ }^{1}$ European University of Britanny: Institute of Electronics and Telecommunications of Rennes, INSA, UMR CNRS 6164, 35708 \\ Rennes, France, \{tony.makdissy, raphaël.gillard, erwan.fourn\}@insa-rennes.fr \\ ${ }^{2}$ Thales Alenia Space: Research and Development Department, 31037 Toulouse, France, etienne.girard@thalesaleniaspace.com
}

\begin{abstract}
This paper presents an enhanced version of the triple-slot phase-shifting cell topology previously studied. It consists in reducing the size of the unit cell in order to enlarge its bandwidth and to minimize the detrimental effect of the angle of incidence on its behavior. Simulations demonstrate that the cell preserves a satisfying performance over a wide frequency band, even when it is illuminated with a high angle of incidence in both polarizations.
\end{abstract}

Index Terms-reflectarray antennas, phase-shifting cell, single linear polarization.

\section{Introduction}

Microstrip printed reflectarrays have been extensively studied in the past two decades. They offer the possibility of forming complex radiation patterns with relative simplicity, low cost, low losses and low profile.

In passive structures, the unit cell usually uses patches [1], slots [2] or stubs [3] to control the phase of the reflected wave. These structures suffer generally from two major limitations: the insufficient phase range and the limited bandwidth. This second limitation has confined for a long time this type of antennas to narrowband applications. In order to overcome these limitations, several resonators are generally combined on a single layer or a multilayer substrate $[4,5]$. However, single layer solutions are preferable as they result in a simpler technological process.

In active reflectarrays, the reflected phase has to be controlled dynamically with a reduced number of reconfigurable elements, such as PIN diodes [6], varicap diodes [7] and MEMS switches [8], loading the unit cell. This permits to preserve a low cost antenna.

While designing a reconfigurable reflectarray, one of the main challenges is thus to design a phase-shifting cell whose phase can be controlled dynamically over a $360^{\circ}$ range with a reduced number of reconfigurable elements and over a large bandwidth. A possible candidate is the triple-slot phaseshifting cell presented in [9].

In [10], it has been shown that the bandwidth of the unit cell can be improved by reducing its size. Here, we demonstrate that this reduction on the size of the cell can also enhance its robustness versus the angle of incidence as it will be shown on the triple-slot topology.

\section{Impact of the Incidence on the Behavior of the Cell}

\section{A. Initial Performances of the Cell Under Normal Incidence}

The proposed cell, illustrated in Fig. 1, is identical to the cell presented in [9]. The only difference lies in the variable capacitance loading the central slot. It is modeled here with a lumped element (in red) instead of the gap capacitance of variable length. The cell is $35 \mathrm{~mm}$ in size $(\mathrm{m}=35 \mathrm{~mm})$, printed on a substrate with 2.17 dielectric constant and $1.6 \mathrm{~mm}$ thickness, suspended $15.7 \mathrm{~mm}$ above a square metallic cavity. It is simulated using $\mathrm{HFSS}^{\circledR}$ electromagnetic simulator assuming an infinite periodic array. Initially, the cell is supposed illuminated with a plane wave under normal incidence. Four uniformly distributed phase states can be obtained respectively for the values $\{10 \mathrm{fF}, 57 \mathrm{fF}, 77 \mathrm{fF}$ and $123 \mathrm{fF}$ of the variable capacitance loading the central slot (Fig. 2 ). The bandwidth of the cell is defined for losses less than $1 \mathrm{~dB}$ and for a phase resolution better than 1.79 equivalent bit. This resolution corresponds to a phase standard deviation [11] better than $30^{\circ}$. In our case, Fig. 3 clearly shows that losses are less than $1 \mathrm{~dB}$ all over the band, and the phase standard deviation (Fig. 4) takes values less than $30^{\circ}$ between $5 \mathrm{GHz}$ and $5.65 \mathrm{GHz}$ which results in $12.2 \%$ of bandwidth.

\section{B. Performances of the Cell Under Oblique Incidence}

A unit cell must operate over a range of angle of incidence representative of the real illumination conditions of the array. To assess this effect, the cell is now placed in an infinite periodic array. It is illuminated with a plane wave under oblique incidence (Fig. 5). Fig. 6 and Fig. 7 clearly show that when the cell is illuminated with an oblique incidence, in both TE and TM polarizations, the variation of the phase standard deviation versus the frequency is deteriorated. This demonstrates the detrimental effect of the oblique incidence on the behavior of the cell and on the bandwidth. Indeed, for a $30^{\circ}$ angle of incidence, the phase standard deviation quickly tends to $30^{\circ}$ in TE polarization and the bandwidth is reduced to $4.8 \%$ $(5-5.25 \mathrm{GHz})$. The situation is even worse for TM polarization as no frequency point complies with the standard phase deviation requirements when the incidence angle is $30^{\circ}$. Hence the need to improve the robustness of the cell regarding 
oblique incidence. To do so, the size of the cell has to be reduced as it will be demonstrated in the next section.

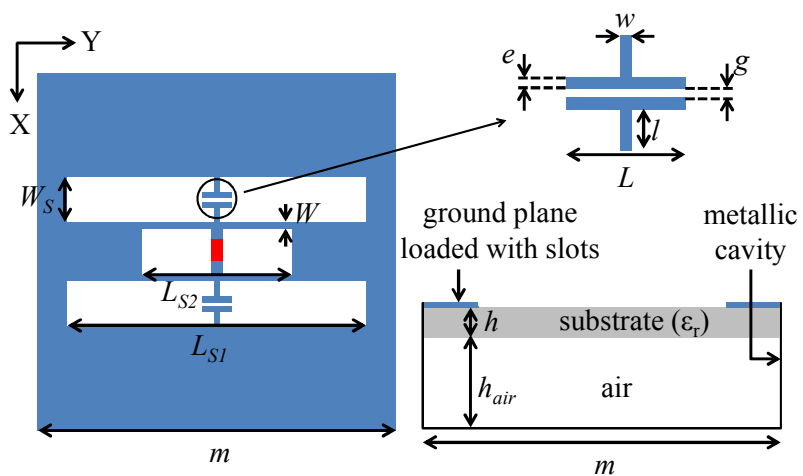

Fig. 1. Phase-shifting cell: $\mathrm{L}_{\mathrm{S} 1}=23 \mathrm{~mm}, \mathrm{~L}_{\mathrm{S} 2}=11 \mathrm{~mm}, \mathrm{~W}_{\mathrm{S}}=5 \mathrm{~mm}, \mathrm{~W}=0.2 \mathrm{~mm}$ $\mathrm{w}=0.5 \mathrm{~mm}, \mathrm{e}=\mathrm{g}=0.2 \mathrm{~mm}, \mathrm{l}=2.2 \mathrm{~mm}, \mathrm{~L}=1 \mathrm{~mm}, \mathrm{~h}=1.6 \mathrm{~mm}, \varepsilon_{\mathrm{r}}=2.17, \mathrm{~h}_{\text {air }}=15.7 \mathrm{~mm}$

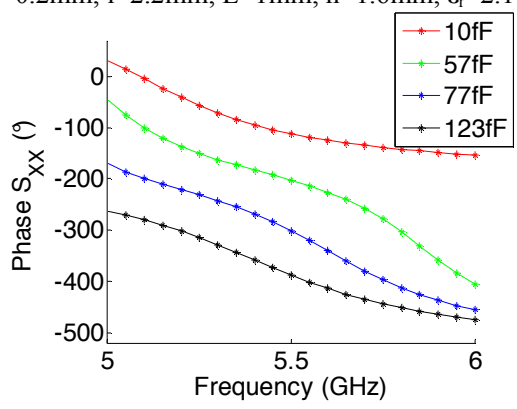

Fig. 2. Reflected phase versus frequency, of the cell of size $m=35 \mathrm{~mm}$, for the four states obtained with the convenient values of the variable capacitance

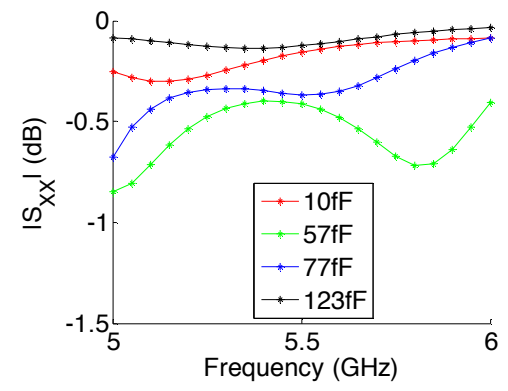

Fig. 3. Losses versus frequency, of the cell of size $m=35 \mathrm{~mm}$, for the four states obtained with the convenient values of the variable capacitance

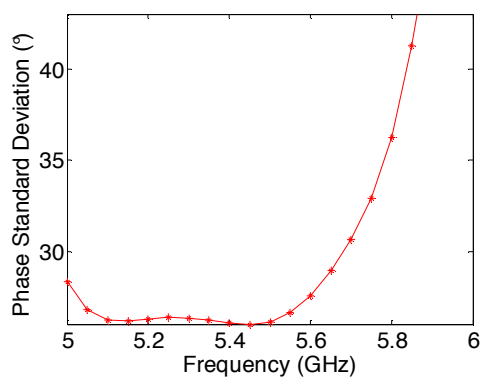

Fig. 4. Phase standard deviation versus frequency of the cell of size $\mathrm{m}=35 \mathrm{~mm}$
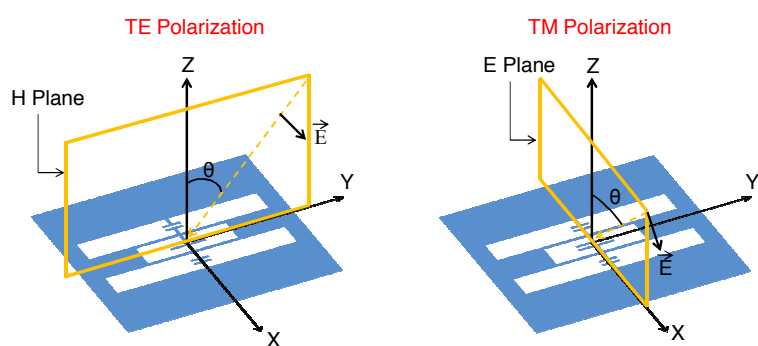

Fig. 5. Phase-shifting cell under oblique incidence (considering $\mathrm{x}$ polarization)

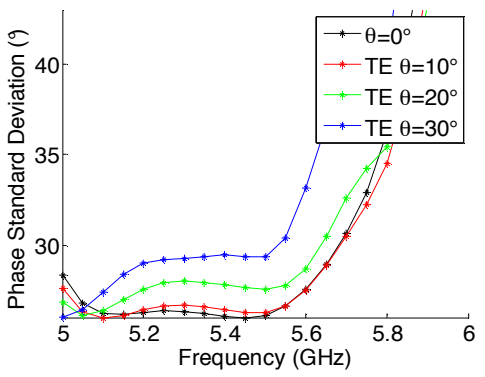

Fig. 6. Phase standard deviation versus frequency, of the cell of size $\mathrm{m}=35 \mathrm{~mm}$, for different angle of incidence in TE polarization

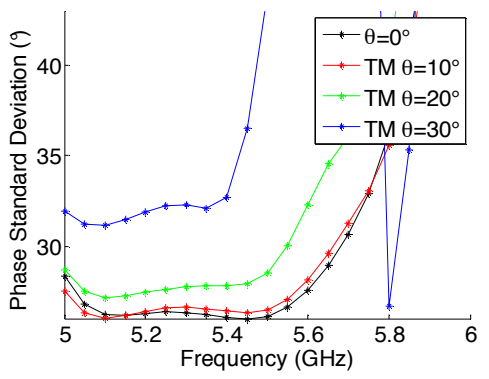

Fig. 7. Phase standard deviation versus frequency, of the cell of size $\mathrm{m}=35 \mathrm{~mm}$, for different angle of incidence in TM polarization

\section{Phase-Shifting Cell of Reduced Size}

The size of the cell, illustrated in Fig. 1, is now $\mathrm{m}=28 \mathrm{~mm}$ instead of $35 \mathrm{~mm}$, and the other dimensions $\left(\mathrm{L}_{\mathrm{S} 1}, \mathrm{~L}_{\mathrm{S} 2}, \mathrm{~W}_{\mathrm{S}}, \mathrm{W}\right.$, etc...) are maintained identical. The cell is simulated in an infinite periodic array and illuminated with a plane wave under normal incidence. The four new convenient values of the central slot capacitance, for which four uniformly distributed phase states are obtained, are $\{10 \mathrm{fF}, 42 \mathrm{fF}, 62 \mathrm{fF}$ and $150 \mathrm{fF}\}$ (Fig. 8). The bandwidth for which losses (Fig. 9) are less than $1 \mathrm{~dB}$ and the equivalent bit number is better than 1.79 (Fig. 10) is here $15.65 \%(5.3-6.2 \mathrm{GHz})$ instead of $12.2 \%$ when $\mathrm{m}=35 \mathrm{~mm}$. Moreover, Fig. 11 and Fig. 12 clearly show that reducing the size of the cell permits to preserve a satisfying bandwidth even for high angle of incidence. Indeed, a minimum bandwidth of $12 \%(5.45-6.15 \mathrm{GHz})$ is obtained for an incidence of $30^{\circ}$ in TM polarization. 


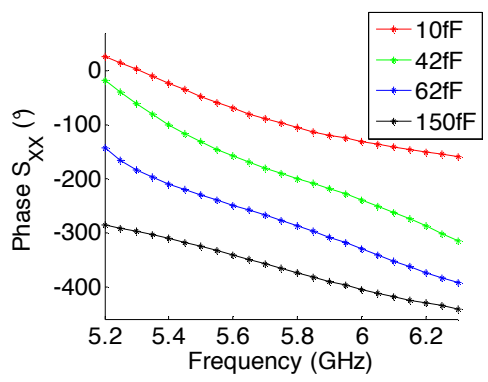

Fig. 8. Reflected phase versus frequency, of the cell of size $\mathrm{m}=28 \mathrm{~mm}$, for the four states obtained with the convenient values of the variable capacitance

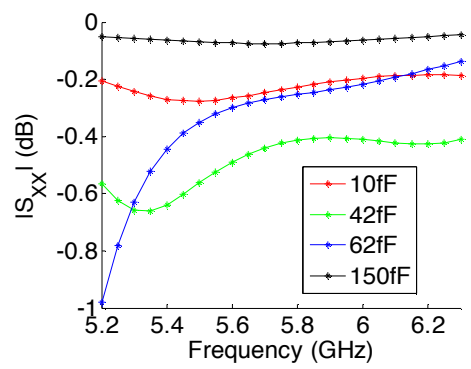

Fig. 9. Losses versus frequency, of the cell of size $m=28 \mathrm{~mm}$, for the four states obtained with the convenient values of the variable capacitance

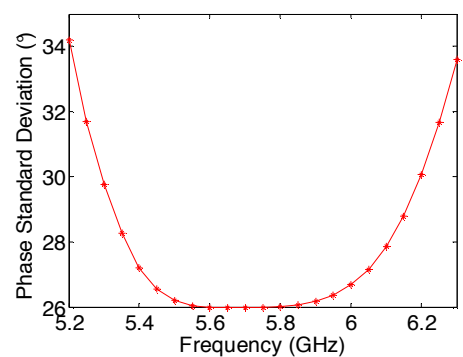

Fig. 10. Phase standard deviation versus frequency of the cell of size $\mathrm{m}=28 \mathrm{~mm}$

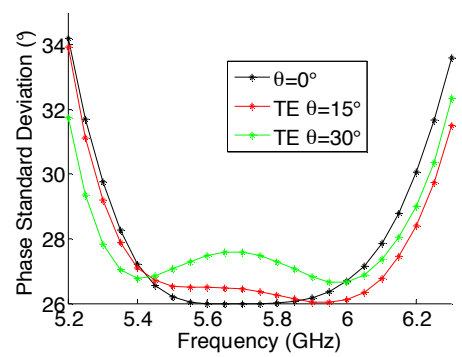

Fig. 11. Phase standard deviation versus frequency, of the cell of size $\mathrm{m}=28 \mathrm{~mm}$, for different angle of incidence in TE polarization

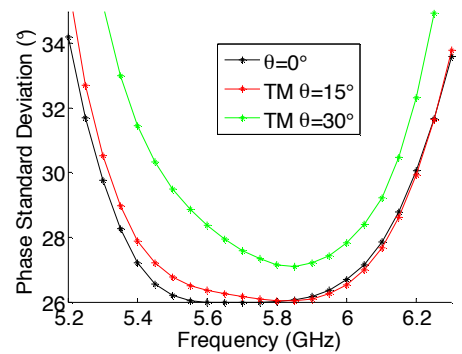

Fig. 12. Phase standard deviation versus frequency, of the cell of size $\mathrm{m}=28 \mathrm{~mm}$, for different angle of incidence in TM polarization

\section{Conclusion}

In this paper we demonstrated that the initial triple slot phase-shifting cell suffers from a major limitation. Its bandwidth is severely reduced when it is illuminated under an oblique angle of incidence. Reducing the size of the cell can improve its robustness regarding this effect. A minimum bandwidth of $12 \%$ is demonstrated for a $30^{\circ}$ angle of incidence, even for TM polarization (the most critical one). In the final version of the article, a complete interpretation of the effect of the angle of incidence on the behavior of the cell will be presented. Moreover, an auto-correction technique of the effect of the incidence will be given.

\section{References}

[1] S. D. Targonski, D. M. Pozar, "Analysis and design of a microstrip reflectarray using patches of variable size," IEEE symposium on antenna and propagation digest, vol. 3, pp. 1820-1823, 1994.

[2] D. Cadoret, A. Laisne, R. Gillard, L. Le Coq, and H. Legay, "Design and measurement of a new reflectarray antenna using microstrip patches loaded with a slot," Electronics Letters, vol. 41, no. 11, pp. 623-624, 2005 .

[3] R. D. Javor, X. D. Wu, "Offset-fed microstrip reflectarray antenna," Electronics Letters, vol. 30, no. 17, 1994.

[4] M. R. Chaharmir, J. Shaker, and H. Legay, "Broadband design of a single layer large reflectarray using multi cross loop elements," IEEE Trans. Antennas Propag., vol. 57, no. 10, pp. 3363-3366, Oct. 2009.

[5] J. Encinar and J. Agustin Zornoza, "Broadband design of three-layer printed reflectarrays," IEEE Trans. Antennas Propag., vol. 51, no. 7, pp. 1662-1664, Jul. 2003.

[6] H. Kamoda, T. Iwasaki, J. Tsumochi, and T. Kuki, "60-GHz electrically reconfigurable reflectarray using $\mathrm{p}-\mathrm{i}-\mathrm{n}$ diode," IEEE International Microwave Symposium Digest, pp. 1177-1180, 2009.

[7] L. Boccia, F. Venneri, G. Amendola, and G. Di Massa, "Experimental investigation of a varactor loaded reflectarray antenna," IEEE International Microwave Symposium Digest, vol. 1, pp. 69-71, 2002.

[8] J. Perruisseau-Carrier and A. K. Skrivervik, "Monolithic MEMS-based reflectarray cell digitally reconfigurable over a $360^{\circ}$ phase range," IEEE Antennas Wireless Propag. Lett., vol. 7, pp. 138-141, 2008.

[9] T. Makdissy, R. Gillard, E. Fourn, E. Girard, and H. Legay, "Triple-slot phase-shifting cell loaded with capacitances for reflectarray applications," $6^{\text {th }}$ European Conference on Antennas and Propagation, pp. 3703-3706, 2012.

[10] S. Costanzo, F. Venneri, and G. Di Massa, "Bandwidth enhancement of aperture-coupled reflectarrays," Electronics Letters, vol. 42, no. 23, pp. 1320-1321, 2006.

[11] R. Pereira, R. Gillard, R. Sauleau, P. Potier, T. Dousset, and X. Delestre, "Dual linearly-polarized unit-cells with nearly 2-bit resolution for reflectarray applications in X-band," IEEE Trans. Antennas Propag.,vol. 60, No. 12, pp. 6042-6048, December 2012. 